\title{
Pollution Control and Remediation of the Tanning Effluent
}

\author{
Mwinyikione Mwinyihija* \\ Kenya Leather Development Council, P. O. Box 14480, Nairobi, Kenya
}

\begin{abstract}
Recent advances have been recorded in the tanning industry with biotechnology in principle playing a very important role through related applied research. This review paper demonstrates that a previously tagged tanning sector as the most hazardous can be resolved through adoption of cleaner technologies, waste management and remedial measures that can be put in place. Pollution is depicted stepwise along the leather processing phases with a selected xenobiotic and contaminants identified such as Sodium chlorides, Chromium, Sulphates, Chlorinated phenolics etc. As an interventionist strategy, biological tools using novel techniques of investigation are shown including the aquatic ecosystems. Remedial methods using known threshold in an identified tannery in Kenya is used to comprehend how to scale down the pollutants eventually. However it is recognised that though phytoremediation potential exist, it will require a combination of several other recently developed methods to provide a much firmer basis of controlling pollution loads related to the tanning Industry.
\end{abstract}

Keywords: Bioassay, bioluminescence, ecotoxicology, pollutants, tanning.

\section{INTRODUCTION}

Tanning Industry as an agro-based sector is by far the largest source of hazardous wastes. Previous research has related leather tanning and finishing, as one of the main industries producing hazardous wastes and pollution [1]. It is unfortunate that there are no reliable estimates of the quantity and types of hazardous waste generated in most developing countries. This therefore warrants an immediate inventory on matters of waste generation and methods currently in place to manage such wastes. Approximately 10 $15 \%$ of the wastes produced by industry overall are likely to be hazardous, increasing at a rate of $2-5 \%$ per year [2]. Moreover, there is very little information on hazardous waste production, waste disposal and management practices in most developing countries. The major public concern over tanneries has traditionally been about odours and water pollution from untreated discharges. Important pollutants associated with the tanning industry include chlorides, tannins, chromium, sulphate and sulphides as addition to trace organic chemicals and increasing use of synthetic chemicals such as pesticides, dyes and finishing agents, as well as from the use of newer processing chemical solvents [3]. These substances are frequently toxic and persistent, and affect both human health and the environment [4].

It is critical to note that to-date many diverse environmental impacts of tanneries have made them subject to complex pollution control policies in many countries. For example factory sites, lagoons, storage areas and temporary waste dumps are known to pollute the underlying soil especially so when appropriate management practices are not put in place. This impact has been recognised to debilitate structures [5] and interrupt agro-based activities like farming and animal husbandry as well as potentially degrade ground-

*Address correspondence to this author at the Kenya Leather Development Council, P. O. Box 14480, (00200) Nairobi, Kenya; Tel: 254020 4442321; E-mail:m_mwinyi@hotmail.co.uk water systems. Groundwater contamination occurs when wastewater and chemicals seep through the soil from unlined ponds, pipes and drains, or from dumps and spills. Groundwater may take a long time to cleanse itself because it moves slowly and is out of contact with air [6].

Consequently when the deposition of solids is considered, it becomes apparent that raw unsettled tannery wastewaters can cause encrustation (of calcium carbonate) and serious corrosion of metals as well as concrete sewers (due to $\mathrm{H}_{2} \mathrm{~S}$ biological oxidation to $\mathrm{H}_{2} \mathrm{SO}_{4}$ [7]. Thus high pollutant loads, involving chromium, sulphates, chlorides etc could easily interfere with key biological processes used in sewage treatment plants. In addition these pollutants may also damage the ecology of the receiving terrestrial and aquatic systems in the vicinity of the discharge points [8].

Biological decomposition of organic matter from Industrial waste, as well as sulphide emissions from wastewaters (also due to bacterial reduction of sulphate) [7], are responsible for the characteristic objectionable odours from tanneries in the form of $\mathrm{H}_{2} \mathrm{~S}$ [9]. Potential sources of odour include sulphide emissions from dehairing and waste treatment, ammonia emissions from dehairing and delime liquors and fleshings.

Essentially it is now recognised that direct contact with some industrial chemicals can potentially cause disability, illness (toxigenic/carcinogenic) and death in humans [10]. Minor exposures when frequent can cause the build-up of toxic levels within humans. Solvents from degreasing and finishing are a source of exposure through vapours. Human health can also be affected by toxic hazards through the unskilled and unprotected handling of pesticides, tanning chemicals and treated hides and skins [11]. Also visual impacts, excessive noise and air emissions are known to be associated with the tanning industry.

To understand fully the pollution impact of the leather industry it will be prudent to assess the categories of 
hazardous waste, its identification, exposure assessment, ecological effects and risk characterisation. To identify the toxic nature of the effluent for purposes of pollution control and remediation, bioassays (to evaluate responses to stressors) and chemical analysis (to provide information on the concentration and identification of the stressor) were used during the profiling of tannery waste [8].

\subsection{Categories of Hazardous Waste}

Hazardous wastes do not have a universally accepted definition, but similar definitions are used in many countries and the United Nations Organisations [2]. In the United Nations Environment Programme (UNEP) the definition is:

"Waste other than radioactive wastes which, by reason of their chemical reactivity or toxic, explosive, corrosive or other characteristics causing danger or likely to cause danger to health or the environment, whether alone or coming into contact with other wastes, are legally defined hazardous in the state in which they are generated or in which they are disposed of or through which they are transported".

In the USA, the hazardous waste is:

"One that may cause or significantly contribute to serious illness or death or that poses a substantial threat to human health or the environment when improperly managed".

In the United States, the Environmental Protection Agency (US EPA) defines any waste as hazardous which meets one of the following:

1. Ignitability. Waste that poses a fire hazard during routine management. Fires not only present, immediate dangers of heat and smoke, but also can spread harmful particles over wide areas.
2. Corrosivity. Wastes requiring special containers or segregation from other wastes because of their ability to dissolve toxic contaminants.

3. Reactivity. Wastes that tend to react spontaneously, to react vigorously with air or water, to be unstable to shock or heat, to generate gases or to explode.

4. Toxicity. Wastes that, when improperly managed may release toxicants in sufficient quantities to pose a substantial hazard to human health or the environment.

Tannery effluent, because of its complexity, is associated with the four main characteristics mentioned above (ignitability, corrosivity, reactivity and toxicity). This will therefore form the basis of assessment of tannery effluent wastes (Fig. 1).

\subsection{Bioassays}

Bioassays involve studying biotics (living organism) in responses towards xenobiotics in the environment (e.g. Phytotoxicity, bioluminescence response etc.). Bioassays as an appropriate diagnostic pollution tool have larger variability than most chemical analysis due to biological variation. The major advantage of bioassays is that the total toxicity of wastewater can be assessed by taking into account bioavailability and synergistic or antagonistic effects. Also, transforming information on concentration to information on biological response is useful for risk assessment. Chemical analysis provides information on the concentration of a substance in a sample and may help to identify that substance [12]. However, this does not give direct information relating to the bioavailability and impact of environmental pollutants. The requirements for a bioassay as test to

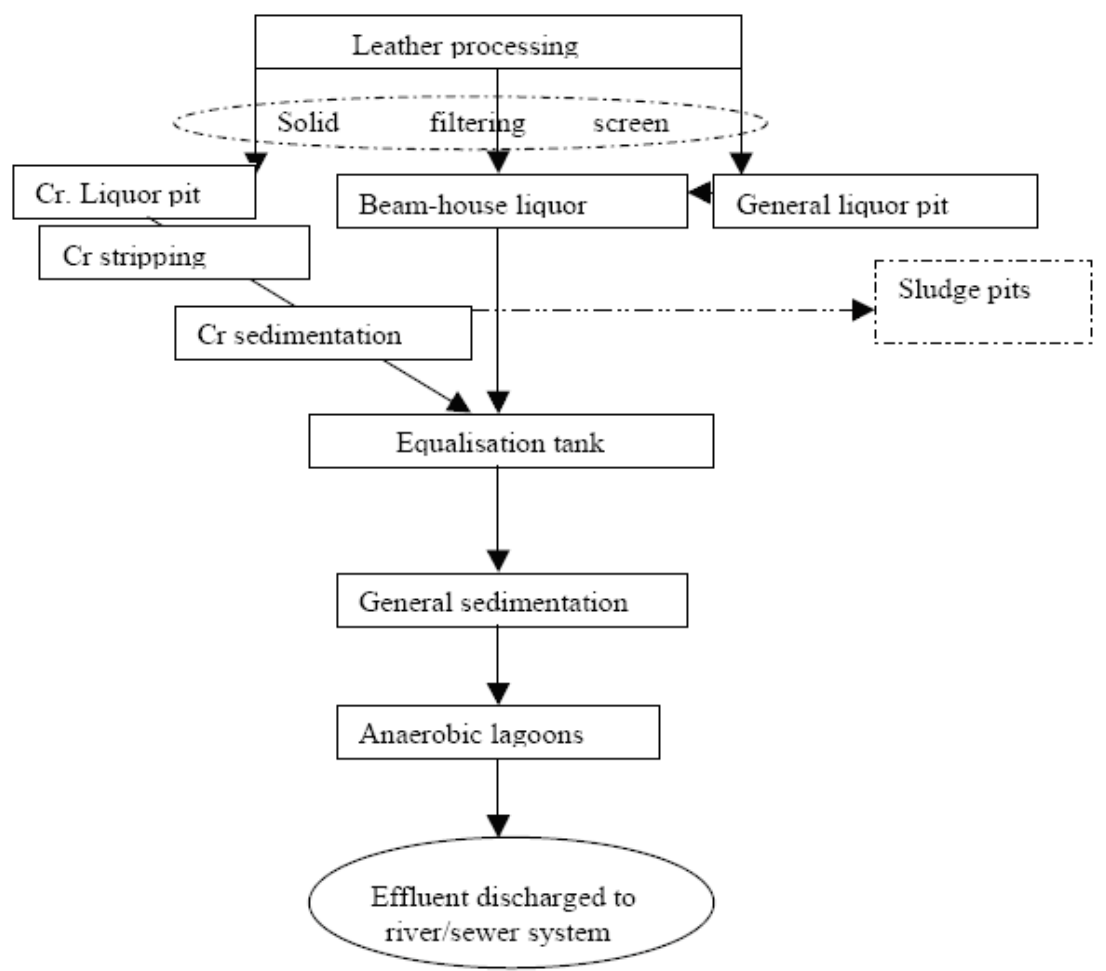

Fig. (1). Flow diagram illustrating effluent treatment in a typical leather processing site in Kenya [11]. 
Table 1. Criteria for the Selection of Type of Test in Environmental Toxicity Assessment [12]

\begin{tabular}{|c|c|c|c|}
\hline & Ecosystem Test & Toxicity Test & \pm \\
\hline \hline Ecosystem relevance & + & - & + \\
\hline Interlaboratory Reproducibility & - & + & + \\
\hline Frequent control & - & + \\
\hline Cost effectiveness & + & + \\
\hline
\end{tabular}

effluents must meet the following criteria: the test should be representative; reproducible; simple to use, inexpensive [12].

Several bioassay system hierarchies that might be considered for the purpose include;

1. Ecosystem tests (e.g. Mesocosm, Microcosm or Biocenosis [13, 14]

2. Toxicity tests with single species (e.g. fish, daphnia, algae); or

3. Sub-organismic test systems (e.g. fish cell tests [15]).

\subsection{Toxicity Test}

Considering the criteria for the selection of appropriate bioassay in environmental toxicity assessment, a toxicity test (rather than ecosystem or sub-organismic test) was identified to be ideal in this study due to its ecosystem relevance, interlaboratory reproducibility and cost effectiveness (Table 1).

\subsection{Evaluation of Biomass Activity in Sediments}

Monitoring of the biomass activity (e.g. intracellular enzyme activity) at the river sediment level can provide vital information on stressor-response and ecological-effects. The activity of certain enzymes and cofactors such as $\mathrm{F}_{420}$, hydrogenase, dehydrogenase (DHA), and adenosine triphosphate (ATP), may serve as indicators of these biological effects [16-18]. DHA and ATP have been used successfully to monitor biomass activity (e.g. in aerobic and anaerobic sludge activity) because the methods of determining them are easy and relatively rapid.

Dehydrogenase is an oxidoreductase soil enzyme and is intracellular, often relatively stable, and can persist for extended periods, thereby providing a longer term perspective than measurements involving extant organisms alone. The impact of pollutants on soil health has been addressed through the measurement of enzyme activity [19]. DHA is measured generally by adding a tetrazolium salt, such as triphenyltetrazolium chloride (TTC) or 2-( $p$-iodophenyl)-3( $p$ nitrophenyl)-5-phenyl tetrazolium chloride (INT), to a biological system [20]. Knowledge of the reduction in sediment capacity to act as a fully functioning mineralisation medium for natural pollutant substrates is critical in overall river health assessment [19].

In presenting this specific paper on pollution control and remediation, there is need to address the following specific objectives:
1. Identify stressors/hazards.

2. Apply biological (Bioassay) and chemical assays (to determine heavy metals, COD, BOD, Total Phenols) to quantify the stressors and their effects on the ecosystem.

3. Determine the probability that the identified stressors (toxic chemicals from the tanning industry) caused a significant impact to the environment (analogous to the statement of purpose of the risk assessment).

4. Implore on the prospect of remediation.

\section{DISCUSSION}

\subsection{Pollution Control Design}

Pollution control related to the tanning Industry entails assessment of the effluent treatment phase (raw effluent, treated effluent (general sedimentation) and final effluent (anaerobic lagoons)), upstream and downstream sampling points. This could also involve observations on visual (water colour, vertebrates and plants) and odorous peculiarities. To determine impacts and effects associated with pollution load, both biological and chemical analysis could be used to identify the class or causative chemicals involved [8].

\subsection{Evaluation of End-Points}

A tangible approach in evaluating the end-points is to comprehend the intricacies of pollution control. Thus it is also important to consider assessing and measuring endpoints to understand the influencing factors behind remediation. Accordingly, the assessment of end-points at the initial stages considers the aquatic receptors (surface and sedimentary levels) of the river (this approach is relevant to aquatic systems). To achieve this assessment end-point, the mortality of primary decomposers (Escherichia coli HB101 pUCD607) and primary consumers (Daphnia magna) as surrogate (trophic levels) species was measured (measurement end-points) $[8,11]$. Based on knowledge of the fate and transport of tannery effluent contaminants in aquatic systems, the ecotoxicity of the contaminants to aquatic organisms were carried out to determine their potency levels. It was demonstrated during the study that tannery effluent contaminants deposited in the sediments were be released to the water column during re-suspension and redistribution of the sediments. Thus the benthic community would therefore be an initial receptor for the contaminants in the sediments [8]. The assessment further indicated that the assessment 


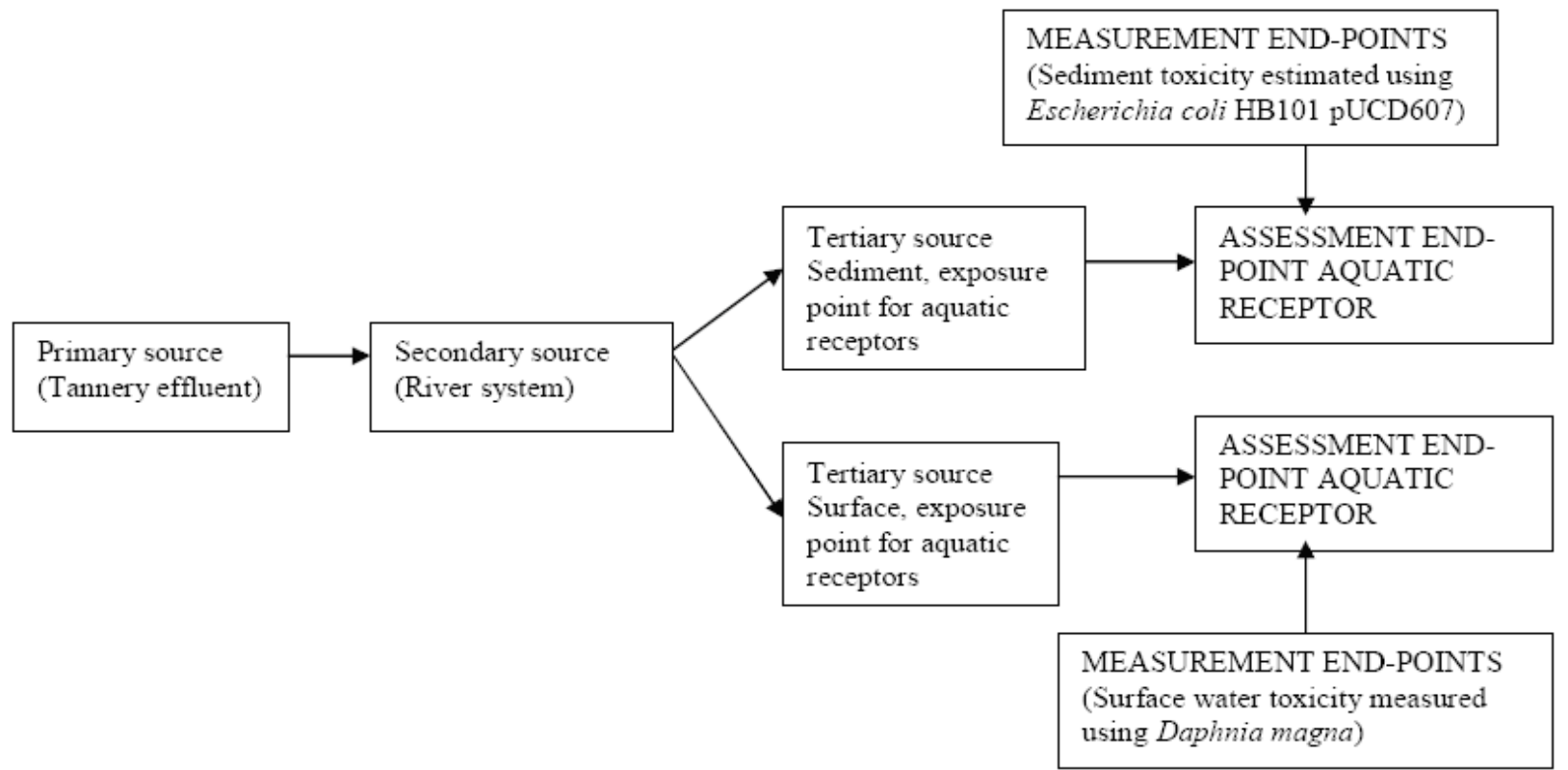

Fig. (2). Conceptual model for the Tannery site showing the primary source of pollution and the measurement end-points for sediment river health (Escherichia coli HB101 pUCD607) and surface water (Daphnia magna) [11].

end-point for the study site, literary showed that the protection of surface river water (as depicted by the Daphnia magna test) and sediments (carried out by using Escherichia coli HB101 pUCD607) (aquatic receptors) from toxicity was caused by tannery effluent contaminants that concentrate or pre-concentrate in aquatic receptors. A measure of biomass activity (dehydrogenase) also, further provides the river sediment health status (comparing upstream and downstream sampling points) in relation to the stressor impact [8]. Based on this information, two assessment-end-points were identified: 1). Maintaining river surface water quality, 2). Protecting river sediment health.

The diagram (Fig. 2) identifies the primary, secondary and tertiary sources of the tannery effluent contaminants at the study site, as well as end-point aquatic receptors that could be exposed.
A few selected effects (Table 2) have been identified and their associated impact described. Thereafter the same will be discussed to understand the basis of controlling the pollution;-

\subsubsection{Effect of Chloride}

The high chloride content in the effluent $(1693.7 \pm 757.4$ $\mathrm{mg} \mathrm{L}^{-1}$ ) can affect aquatic plants and certain species of animals. Each species adapted to low salinities have a certain range of salinities within which they can survive. However, animals not affected by salinity may be indirectly affected by habitat modification and altered food supply. Aquatic invertebrates, macrophages and plants are generally affected (e.g. in plants, a reduction in growth rates, leaf production and die-back of the growth tips is observed) at salinities over $1000 \mathrm{mg} \mathrm{L}^{-1}$, while more than $4000 \mathrm{mg} \mathrm{L}^{-1}$ affects the survival of some common macrophytes [3]. Related studies

Table 2. Characterisation of the Kenyan Tannery Effluent Showing Identified Parameters and Levels in Three Main Phases (Raw Effluent, Treated Effluent and Final Effluent) $(n=5)[8]$

\begin{tabular}{|c|c|c|c|c|}
\hline Parameters & Raw Effluent & $\begin{array}{c}\text { Treated Effluent } \\
\text { (General Sedimentation) }\end{array}$ & $\begin{array}{c}\text { Final Effluent } \\
\text { (Anaerobic Lagoons) }\end{array}$ & LSD (5\%) \\
\hline $\mathrm{pH}$ & $7.72(0.19)$ & $7.1(0.1)$ & $7.66(0.24)$ & 0.58 \\
\hline COD & $2437.84(660.3)$ & $5978.16(4626.1)$ & $1307.4(291.4)$ & 8329 \\
\hline BOD & 1255 (309.9) & $5738.1(4688.7)$ & $438.5(194.9)$ & 8366 \\
\hline $\mathrm{Cl}$ & $1725(495.5)$ & 483.9 (216.4) & $1693.7(757.4)$ & 1719 \\
\hline Sulphide & $62.4(14.7)$ & $57.2(15.1)$ & $89.96(26)$ & 60 \\
\hline Susp. Solids & $562(121.6)$ & $448.2(153)$ & $330.67(43.3)$ & 394 \\
\hline Total Cr & $23.02(18.3)$ & $1.71(0.4)$ & $0.93(0.2)$ & 33 \\
\hline Oil/grease & $332.3(108.2)$ & $273.9(101)$ & $94.38(31)$ & 267 \\
\hline
\end{tabular}

Figures in parenthesis are SEM's (Standard errors of means). 
has shown that $9 \mathrm{~g} \mathrm{~L}^{-1}$ of chloride could represent a considerable problem for biological plants [21]. Moreover the impact of curing effluent on terrestrial ecosystems was found as a cause to aridity on impacted soils [5].

\subsubsection{Effect of $\mathrm{BOD} / \mathrm{COD}$}

Both BOD and COD levels were highest at the general sedimentation phase (BOD $5978 \mathrm{mg} \mathrm{L}^{-1}$, COD $5978 \mathrm{mg} \mathrm{L}^{-1}$ ) of the tannery effluent treatment pits, with the levels drastically reducing in the final effluents (BOD $438 \mathrm{mg} \mathrm{L}^{-1}$, COD $1307 \mathrm{mg} \mathrm{L}^{-1}$ ) after the anaerobic lagoons. Beam-house operations involving soaking, liming and deliming processes generate large quantities of waste such as wastewater (up to $400 \%$ during liming and reliming process) consumed in proportion to the weight of the treated hides [22]. The discharged water is full of dissolved substances, which affect its quality. The Beam-house mainly affects the following parameters of water effluent; COD, suspended solids, chlorides, sulphides and organic nitrogen. Conventional liming-reliming processes lead to $35-45 \mathrm{~kg}$ of biological oxygen demand (BOD), 100-125 kg of chemical oxygen demand and $140-160 \mathrm{~kg}$ of total solids (TS) for every ton of raw skins/hides processed [23].

\subsubsection{Effect of Sulphide}

Sulphide levels increased during the treatment phases when raw effluent $\left(62.4 \mathrm{mg} \mathrm{L}^{-1}\right)$ was compared to the final effluent (anaerobic lagoons) (89.96 $\left.\mathrm{mg} \mathrm{L}^{-1}\right)$. The increase in sulphide content in the final effluent lagoons was due to the increasing anaerobic conditions that cause a reversion of sulphates to sulphides. Sulphate and sulphide combinations have a variety of potential health (sulphide forming obnoxious and toxic $\mathrm{H}_{2} \mathrm{~S}$ gas) and environmental impacts and cause damage to structures (Sulphates accelerates corrosion of concrete sewers) [4, 7]. Sulphide is not only toxic for higher organisms, it is also known as an inhibiting substance in anaerobic microbial processes [24].

\subsubsection{Effect of Phenols}

Chlorophenols are the most predominant phenolic compounds in the tanning industry. Chlorophenols can enter the environment through accidental spills, illegal release of industrial and municipal wastewater and excessive use of pesticides [25]. Chlorophenols are used as preservatives for a number of materials such as wood, textiles and leather. Chlorophenols are well known for their biocidal activities and have been found to be toxic, possibly mutagenic to terrestrial biota [26]. Studies on toxicity of chlorophenols have been conducted involving plants (e.g. Lemna gibba) [27], Fish (e.g. Pimphales promelas, Cyprinodon variegates, Poecilia reticulata) [28], earthworms (e.g. Lumbricus terrestris, Eisenia foetida) [29], Protozoa (e.g. Tetrahymena pyriformis) [30] and micro-organisms (e.g. Rhodococcus chlorophenolicus) [31] (e.g. Pseudomonas putida MT-2, Pseudomonas putida 50026, Rhodococcus erythropolis A177) [32] and (Rhizobium leguminosarum bioavar trifolii) [33].

\subsubsection{Preview of Tanning and Post Tanning Operations}

Tanning operations and post tanning operations (contribute to the remaining $40 \%$ of the total pollution) consume quantities of water in proportion to the weight of the hides washed, and produce pollution in the effluent water, consisting of COD, surfactants, chlorides, sulphates, ammonium-N and $\mathrm{Cr}^{3+}$. The effluent from the dyeing operations, which, per unit of product processed is smaller than, that from previous phases is discharged, at modified values of temperature, COD, ammonia nitrogen, phenolics compounds and fats. Finishing operations, and in particular the surface application of the products affect the quality of emissions into the atmosphere as regards particulate dust and volatile organic substances (VOS) [4].

To complement the bioassay, river sediments were analysed for heavy metals as already discussed earlier. The speed and the depth of the river at the discharge point (1.17

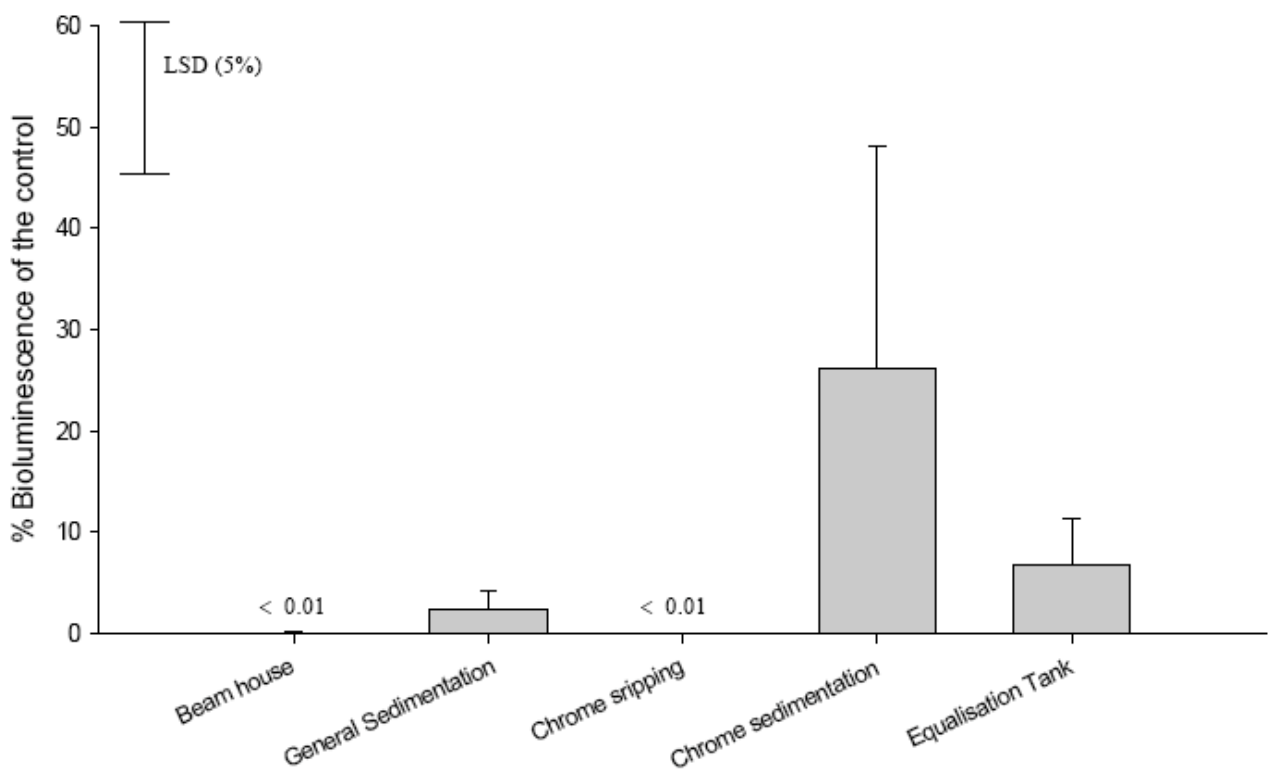

Sampling points

Fig. (3). Toxicity (percentage bioluminescence) of different effluent treatment pits [8]. 
$\mathrm{m} \mathrm{s}^{-1}$ (high water levels - rainy seasons) to $0.513 \mathrm{~m} \mathrm{~s}^{-1}$ (reduced water flow period low rainy seasons)) were observed in a related study. This was a deliberate move to understand the river dynamics and dilution factor of the river. Indeed, this is an important approach towards developing appropriate mechanism in pollution control and remediation.

\subsection{Remediation and Control}

Total chromium levels were highest at the chrome stripping $\left(22.58 \mathrm{mg} \mathrm{L}^{-1}\right)$ and chrome sedimentation tank (191.47 $\mathrm{mg} \mathrm{L}^{-1}$ ) (Fig. 2). The riverine system showed higher levels of chromium in the sediments at $200 \mathrm{~m}\left(1.65 \mathrm{mg} \mathrm{L}^{-1}\right)$

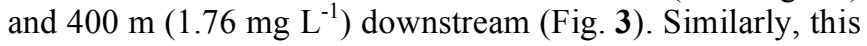

trend was observed for all the metals analysed. This suggested a settling out of solution of the metals to the sediment as the speed of the river slowed downstream (between 0.68 and $0.40 \mathrm{~m} \mathrm{~s}^{-1}$ ) in comparison to the discharge point (between 1.17 and $0.51 \mathrm{~m} \mathrm{~s}^{-1}$ ). Further analysis for total phenols showed none detected at any of the points upstream, but $30 \mathrm{mg} \mathrm{L}^{-1}$ was observed at the discharge point, progressively diluting downstream (Fig. 3).

The anaerobic lagoons (Fig. 4) showed stimulation of the bioluminescence (values $>100 \%$ ) possibly due to the presence of organic compounds. Anaerobic lagoons cause sedimentation of suspended solids, partial conversion of COD to methane gas and conversion of sulphide into sulphates and production of biological sludge [34]. Further scrutiny in the

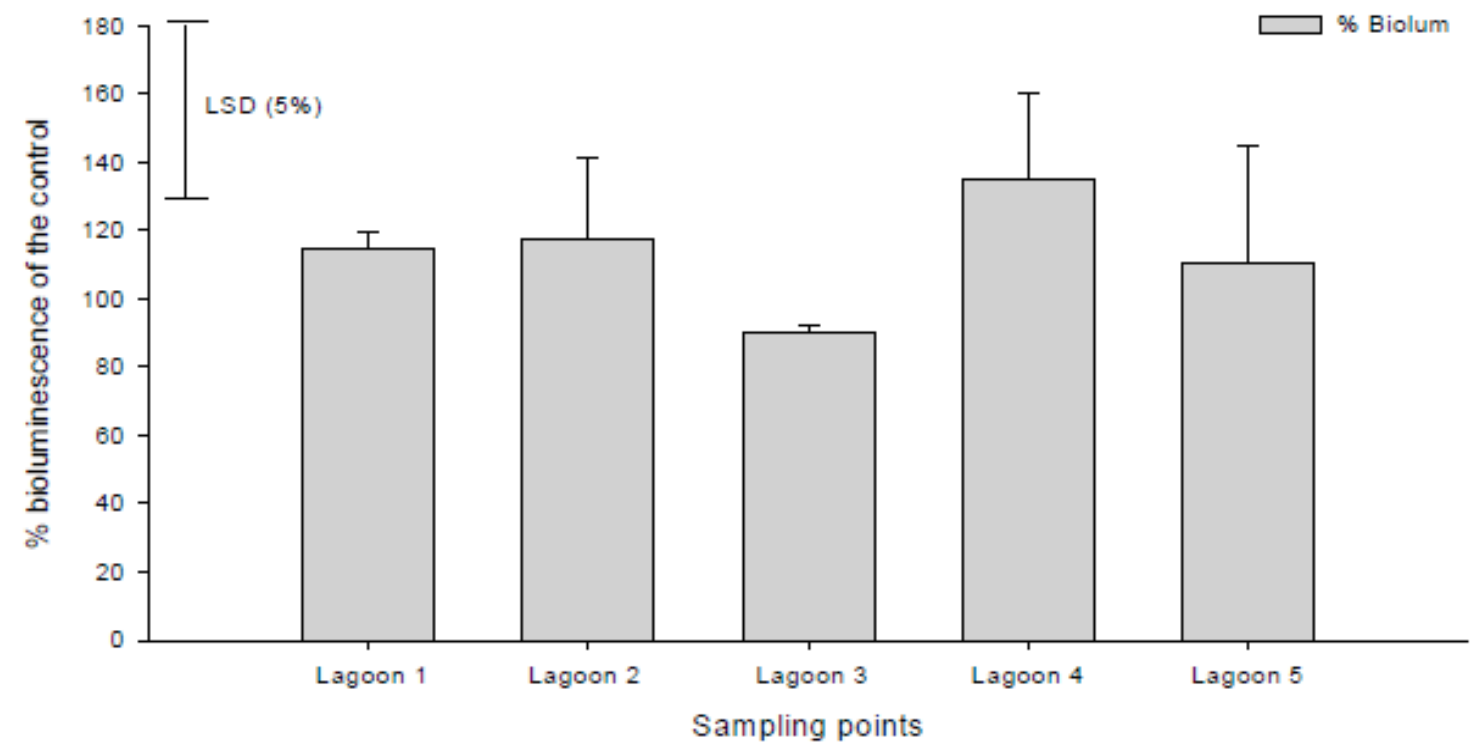

Fig. (4). Toxicity (\% bioluminescence) of interconnected anaerobic lagoons [8].

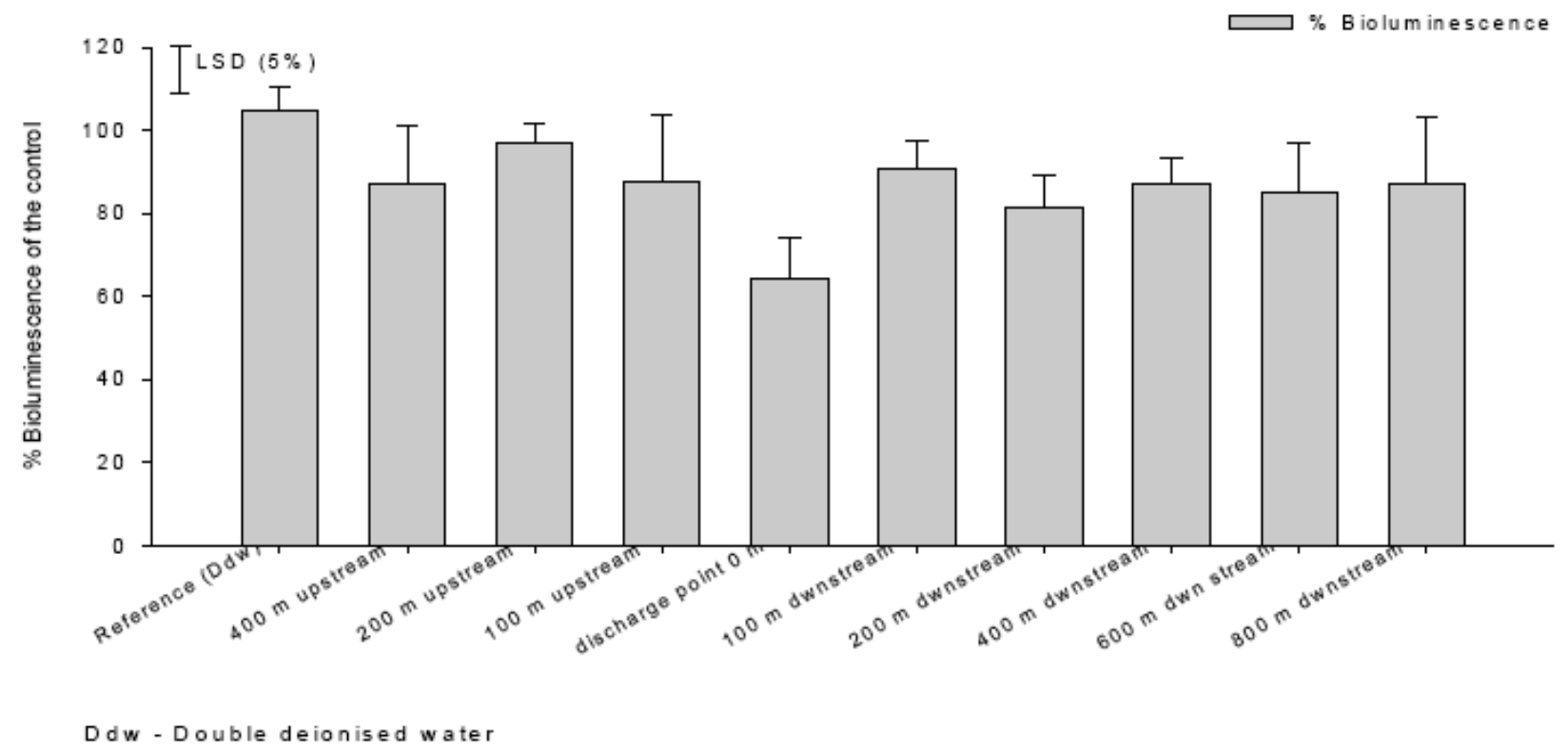

Sampling points

Fig. (5). Toxicity (\% bioluminescence) of various upstream and downstream sampling points in a river ecosystem [39]. 
tanning industry indicates that Sulphur occurs organically in different compounds in highly loaded wastewaters, as organic or inorganic sulphur of various oxidation numbers [24]. Study of luminescence stimulation by chlorophenols found that there is a relationship between higher stimulation of light output and higher EC50 values with lux-marked biosensors [35-37]. A mechanism involving release of fatty acids provided an increase in substrate for the luminescence reaction and therefore an increase in light output [38]. At the discharge point, values for both D. magna (LD85) and percentage bioluminescence (64\%) (Fig. 2) indicated higher levels of stress. The recovery of the river downstream was observed.

Comparatively, the anaerobic lagoons showed no marked differences when values for both D. magna and percentage bioluminescence were compared (Table 3, Fig. 5). However low LD (LD 50) and higher bioluminescence ( $>80 \%)$ values noted at $800 \mathrm{~m}$ demonstrated the recovery of the river downstream.

\subsection{Ecological Effects/Toxicity Assessments}

Field observation and controlled laboratory work provided added information during this phase. The cause and effect-relationship results showed that, at different point's, toxicity varied and was influenced by different groups of contaminants (heavy metals, suspended solids/colloidal materials, and phenols). The analyses at all the stages from raw effluent to the final sampling point in the river were carried out as earlier indicated. The biosensor (Escherichia coli HB101 pUCD607) provided acute toxicity data for the stressor during the effluent treatment phase and flow towards the aquatic receptors showing areas that were high in toxicity (effluent discharge point). Similarly, biomass activity demonstrated the impact of the stressor on the river sediment by showing low values $\left(\mu \mathrm{gTFg}^{-1}\right.$ Sediment $6 \mathrm{~h}^{-1}$ ) within the discharge point areas in comparison to areas upstream (200 $\mathrm{m}, 100 \mathrm{~m})$ and further downstream $(600 \mathrm{~m}, 800 \mathrm{~m})$ (Fig. 6). The combination of the exposure-analysis data with the ecological-effects data resulted in a stressor-response profile [39]. This profile represented an attempt to match ecosystem impacts to the levels of stressor concentration under study.

\subsubsection{Contamination Levels for Identified Pollutants}

The stressor profile was compared to the maximum contaminant levels (MCLs) of identified pollutants (parameters investigated) permitted in water for domestic use (Table 3). This stretch is impacted by a tannery effluent discharge and serves as the main water source (domestic and agricultural use) for the local population (estimated at 3500 in 2004). The levels analysed in the current study exceeded the stipulated levels of all the parameters. This demonstrated the ecological effects and the potential human risk the tannery effluent posed.

Table 3. Maximum Contaminant Levels (MCLs) for Identified Pollutants in Drinking Water Used as the Target for Final Effluent Tannery Discharge [8]

\begin{tabular}{|c|c|c|}
\hline Parameter & MCLs (mg/l) & References \\
\hline \hline COD & 200 (Germany) & {$[4,8]$} \\
\hline BOD & $100($ UK) & {$[4]$} \\
\hline$*$ Cl & 250 (USA) & {$[4,8]$} \\
\hline Sulphide & 2.0 (India/France) & {$[8]$} \\
\hline SS & $60($ UK) & {$[4,8]$} \\
\hline Cr & $0.1($ USA) & {$[4,8]$} \\
\hline Grease/oil & 20 (Switzerland) & {$[8]$} \\
\hline
\end{tabular}

*Recommended but none enforceable guideline.

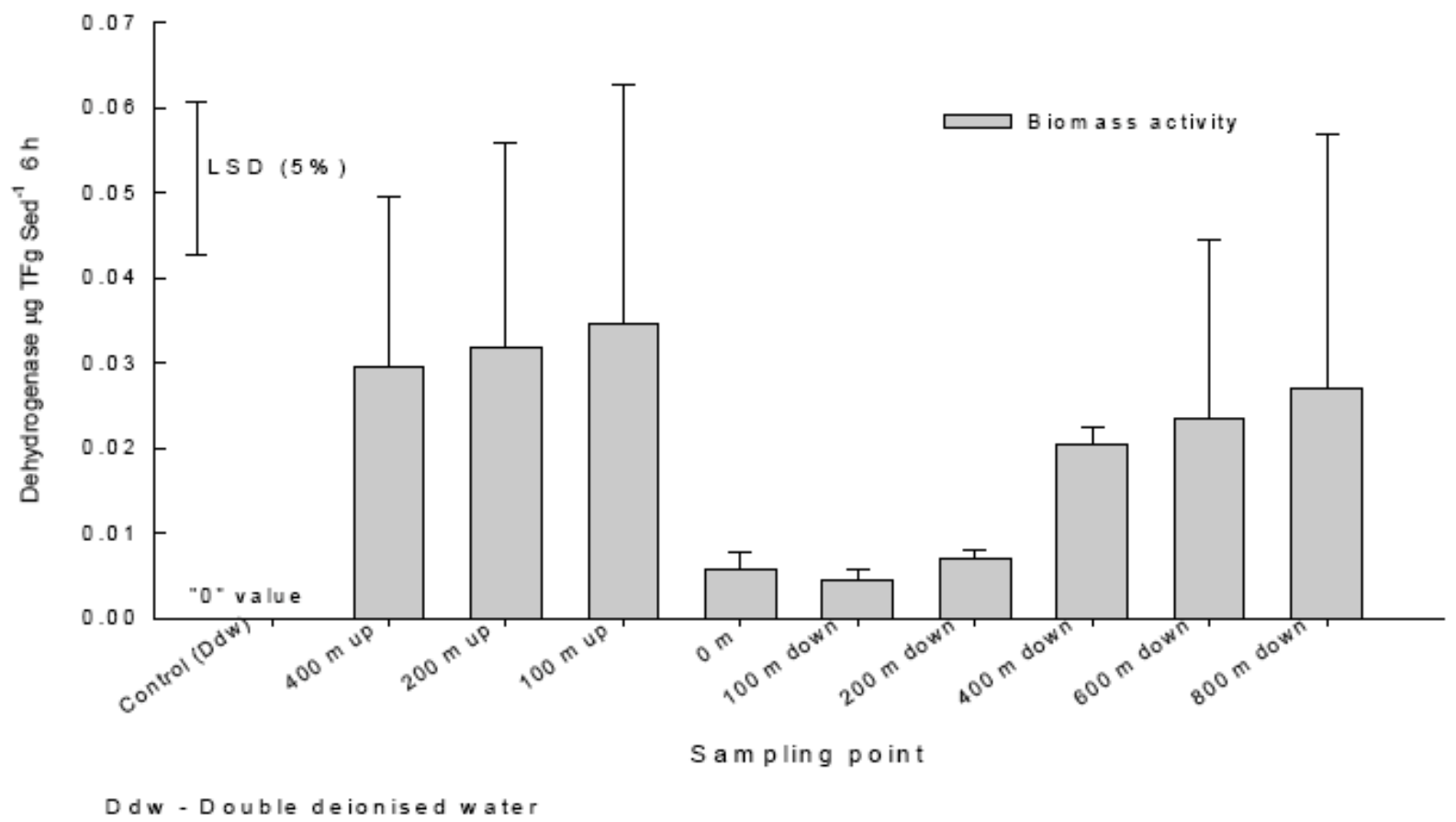

Fig. (6). Measurement of dehydrogenase $\left(\mu \mathrm{gTFg}^{-1}\right.$ Sediment $\left.6 \mathrm{~h}^{-1}\right)$ both upstream and downstream as a measure of biomass activity in the river sediment $(\mathrm{n}=9)[8,39]$. 
Initially maximum tolerable levels of tannery effluent were discussed in comparison to the study site to determine trends worldwide of tannery waste standards. However, when the Kenyan tannery contaminants on final effluent were specifically compared to permitted levels (Table 3 ), all the parameters exhibited exceedances.

\subsection{Phyto-Remediation Potential}

Biosensor based toxicity dissection of tannery and associated environmental samples highlighted the complexicity of toxic pollutants in effluent from the tanning industry and identified possible remediation strategies. However, the future use of indigenous organisms as biosensors should enable exploration of adaptability and acquired resistance over time to pollutants in such areas. Thus the potential of remediation has been made for other trace metals such as Arsenic on lentil plants where uptake was demonstrated [40].

In addition, during the field survey related to this study, a certain type of plant (Ricinus communis) was observed to grow in a tannery effluent disposal pit (Fig. 7). This

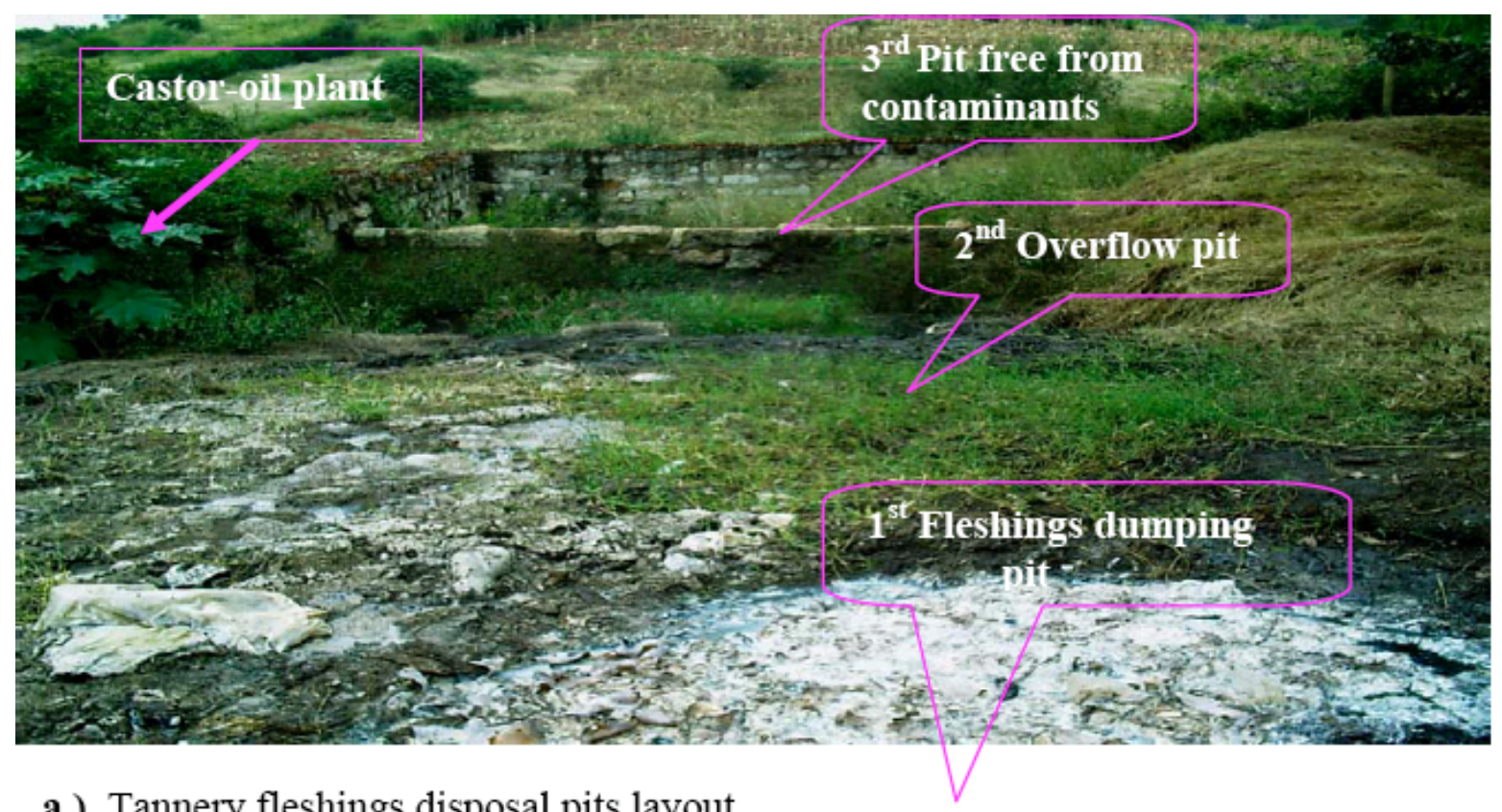

\section{a.) Tannery fleshings disposal pits layout}

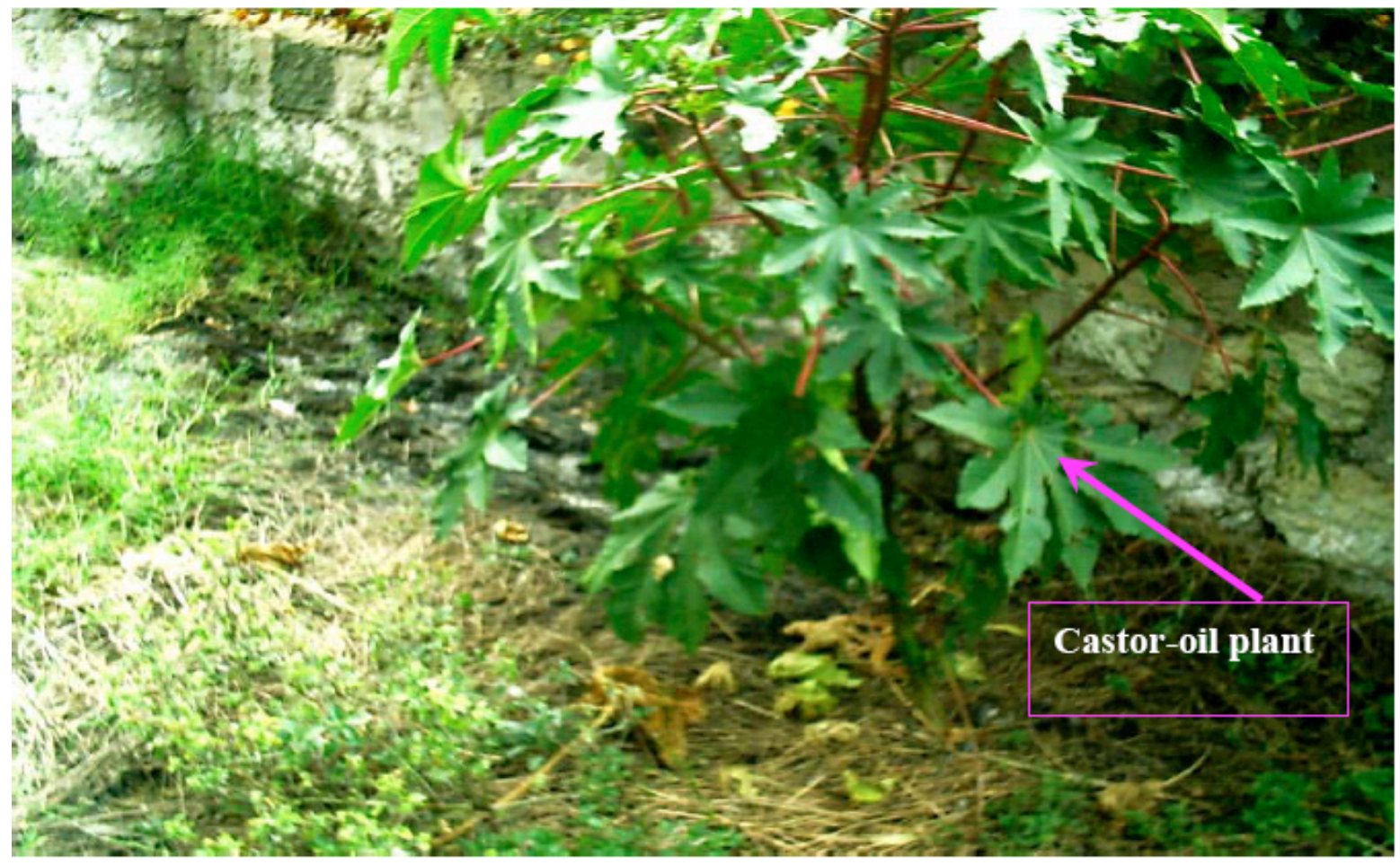

Fig. (7a and b). Thriving Castor oil plant (Ricinus communis) in a Kenyan tannery effluent disposal pit. 
suggested a potential plant-based, decontamination strategy (i.e. phytoremediation). This plant, also commonly known as Castor oil, belongs to the Family Euphorbiaceae and normally grows to an average of 10 to 15 feet. The plant is very variable in habit and appearance with the known varieties being numerous in Africa [41]. The plant is characterised by being drought tolerant, highly toxic if any part of the plant is ingested, grows in soils which are mildly acidic ( $\mathrm{pH} 6.1$ to 6.5) to neutral ( $\mathrm{pH} 6.6$ to 7.5) and it has been observed that moles, voles and other pests are driven away by the plant. It is proposed that a range of studies be carried out to assess the phytoremediative potential of $R$. communis in relation to the tannery effluent. The studies should include both laboratory investigation to explore phtoremediation mechanisms as well as field studies to quantify phytoremediative performance under conditions encountered in the vicinity of Kenyan and other tropical tanneries.

\section{CONCLUSION}

The review paper has dwelt in depth on the issues related to pollution emanating from the tannery environment. This was adequately followed up by reviewing the biological and chemical control methods and eventually investigated the potential that underlies remediation. What is critical for both the identification of the pollutant and understanding its potency is that it facilitates the designing of the remediation exercise easier. This is due to the fact that the science behind aspects of pollutant impact on terrestrial and or aquatic systems will at last reviewable. This paper has therefore addressed the fundamental issues of pollution and remediation strategy and indicated how the tanning industry is currently affected by lack adequate skills processing technology and/on tannery waste management styles. The discussion herein could also assist in developing appropriate tools to carry Life Cycle Assessment especially geared towards the tanning industry in Kenya.

\section{ACKNOWLEDGEMENT}

To all staff of Atlantic International University (AIU) for their support during the post-doctorate studies.

\section{REFERENCES}

[1] Khwaja AR. Studies on Pollution Abatement of Wastes from Leather Industries, $\mathrm{PhD}$ thesis, University of Roorkee India 1998.

[2] Chaaban MA. Hazardous waste source reduction in materials and processing technologies. J Mater Process Tech 2001; 119: 336-43.

[3] Anonymous. Unione Nazionale Industria Conciaria. Environmental report 2009. Available at: www.unic.it (2010).

[4] UNEP IE/PAC, Tanneries and the Environment - A Technical Guide, Technical Report ( $2^{\text {nd }}$ Print) Series No 4, 1994.

[5] Mwinyihija M, Magero J, Chamining'wa GN, Gnanamani A. Characterization of Hides and Skins Curing Process and Resultant Effluent Impact on Soil Profile at Mariakani, Kenya. Congress Proceedings of The $2^{\text {nd }}$ International Leather Engineering Congress, Izmir, Turkiye May $12^{\text {th }}$ to $13^{\text {th }}, 2011 ;$ pp. 63-71.

[6] Wierenga PJ. Physical Processes Affecting Contaminant Fate and Transport in Soil and Water. Pollution Science. In: Pepper LI, Gerba PC, Brusseau, Eds. Academic Press (Elsevier Science, USA), San Diego, California, USA 1996; pp. 53-4.

[7] Balusubramanian S, Pugalenthi, V. A Comparative study of the determination of sulphide in tannery waste water by ion selective electrode (ISE) and Iodimetry. Water Res 2000; 34: 4201-6.
[8] Mwinyihija M. Ecotoxicological Diagnosis in the Tanning Industry - Springer Publisher: New York, USA 2010.

[9] Dorman CD, Brenneman KA, Melanie FS, et al. Fertility and developmental neurotoxicity effects of inhaled hydrogen sulphide in Sprague-Dawley rats. Neurotoxicol Teratol 2000; 22: 71-84.

[10] Murti KCR. Health implications of hazardous wastes disposal. In: Maltezou SP, Biswas AK, Sutter H, Eds. Hazardous Waste Management. Tycooly: London 1989; pp. 191-196.

[11] Mwinyihija M, Meharg A, Strachan NJC, Killham K. Ecological Risk Assessment of the Kenyan tannery industry. J Am Leather Chem Assoc 2005; 100(11): 380-95.

[12] Stuhlfauth T. Ecotoxicological monitoring of industrial effluents, Chapter 14. In: Environmental Toxicology Assessment. In: Richardson M, Ed. Taylor \& Francis, Hertfordshire: United Kingdom 1995; p. 187.

[13] EWOFFT. Summary and Recommendation of the European Workshop on Freshwater Field Tests (EWOFFT). In: Crossland NO, Heimbach F, Hill IR, et al., Eds. Potsdam, Germany 1992; pp. 2-12.

[14] Scholz N, Müller FJ. The riverine biocoenosis model (aquatic stair case model). A test system for determining the ecotoxicity and biodegradation under reality-approximate riverine conditions. Chemosphere 1992; 25: 563-79.

[15] Hansen P-D, Schwanz-Pfitzner I, Tillmanns GM. Ein Fischzellkulturtest als Ergänzungs-oder Ersatzmethode zum Fischtest. Bundesgesundheitsblatt 1989; 32(8): 343-6.

[16] Nybroe O, Jorgensen PE, Henze M. Enzyme activities in wastewater and activated sludge. Water Res 1992; 26(5): 199-202.

[17] Le Bihan Y, Lessard P. Influence of operational variables on enzymatic tests applied to monitor the microbial biomass activity of a biofilter. Water Sci Technol 1998; 37(4/5): 199-202.

[18] Goel R, Minto T, Satoh H, Matsuo T. Enzyme activity under anaerobic and aerobic conditions under activated sludge sequencing batch reactor. Water Res 1998; 32(7): 2081-8.

[19] Killham K, Staddon WJ. Bioindicators and Sensors of Soil Health and the Application of Geostatistics. Enzymes in the Environments; Activity, Ecology and Applications. In: Burns GR, Dick RP, Eds. Marcel Dekker: New York 2002; pp. 397-406.

[20] Hongwei Y, Zhanpeng J, Shaoqi S, Tang WZ. INT-dehydrogenase activity test for assessing anaerobic biodegradability of organic compounds. Ecotoxicol Environ Saf 2002; 53: 416-21.

[21] Cassano A, Molinari A, Romano M, Drioli E. Treatment of the aqueous effluents of the leather Industry by membrane process: a review. J Membr Sci 2000; 181: 111-26.

[22] Thanikaivelan P, Rao RJ, Nair BU, Ramasami T. Approach towards zero discharge tanning: role of concentration on the development of eco-friendly liming-reliming processes. J Clean Prod 2003; 11: 79-90.

[23] Aloy M, Folachier A, Vulliermet B. Tannery and Pollution. Centre Technique Du Cuir. Lyon: France 1976.

[24] Wiemann M, Schenk H, Hegemann W. Anaerobic treatment of tannery wastewater with simultaneous sulphide elimination. Water Res 1998; 32(3): 774-80.

[25] Park J, Dec J, Kim J, Bollag J. Effect of humic constituents in the transformation of chlorinated phenols and anilines in the presence of oxidoreductase enzymes or birnessite. Environ Sci Tech 1999; 33: 2028-34.

[26] Jensen J. Chlorophenols in the terrestrial environment. Rev Environ Contam Toxicol 1996; 146: 25-51.

[27] Hulzebos EM, Adema DMM, Dirven-van Breemen EM, et al. Phytotoxicity studies with Lactuca sativa in soil and nutrient solutions. Environ Toxicol Chem 1993; 12: 1079-94.

[28] Smith S, Furay VJ, Layiwola J, Menezes-Filho JA. Evaluation of the toxicity and quantitative structure-activity relationship (QSAR) of chlorophenols to the copepodid stage of a marine copepod (Tisbe battagliai) and two species of benthic flatfish, the flounder (Platichthys flesus) and sole (Solea solea). Chemosphere 1994; 28: 825-36.

[29] Giggleman MA, Fitzpatrick LC, Goven AJ, Venables BJ. Effects of pentachlorophenol on survival of earthworms (Lumbricus terrestris) and phagocytosis by their immunoactive coelomocytes. Environ Toxicol Chem 1998; 17: 2391-4.

[30] Bryant SE, Schultz TW. Toxicological assessment of biotransformation products of pentachlorophenols: Tetrahymena population growth impairment. Arch Environ Contam Toxicol 1994; 26: 299-303. 
[31] Apajalahti JHA, Salkinoja-Salonen MS. Degradation of polychlorinated phenols by Rhodococcus chlorophenolicus. Appl Microbiol Biotechnol 1986; 25: 62-7.

[32] van Beelen P, Fleuren-Kemila AK. Influence of the $\mathrm{pH}$ on the toxic effect of zinc, cadmium, and pentachlorophenol on pure cultures of soil microorganism. Environ Toxicol Chem 1997; 16: 146-53.

[33] Chaudri AM, McGrath SP, Knight BP, Johnson DL, Jones KC. Toxicity of organic compounds to the indigenous population of Rhizobium leguminosarum biovar trifolii in soil. Soil Biol Biochem 1996; 28: 1483-7.

[34] Balakrishnan PA, Arunagiri A, Rao PG. Ozone generation by silent electric discharge and its application in tertiary treatment of tannery effluent. J Electrostat 2002; 56: 77-86.

[35] Sinclair GM, Paton IG, Meharg AA, Killham K. Lux -biosensors assessment of $\mathrm{pH}$ effects on microbial sorption and toxicity of chlorophenols. FEMS Microbiol Lett 1999; 174: 273-8.

[36] Boyd EM, Meharg AA, Wright J, Killham K. Toxicity of chlorobenzene to a lux-marked terrestrial bacterium, Pseudomonas flourescens. Environ Toxicol Chem 1998; 16: 849-56.
[37]

Sousa S, Duffy C, Weitz H, et al. Use of a lux-modified bacterial biosensor to identify constraints to bioremediation of BTEXcontaminated sites. Environ Toxicol Chem 1998; 17: 1039-45.

[38] Heitzer A, Appegate B, Kehrmeyer S, et al. Physiological considerations of environmental applications of lux reporter fusions. J Microbiol Method 1998; 33: 45-57.

[39] Mwinyihija M, Meharg A, Strachan NJC, Killham K. An ecotoxicological approach to assessing the impact of tanning Industry effluent on river health. Arch Environ Contam Toxicol 2006; 50(3): 316.

[40] Ahmed FRS, Alexander IJ, Mwinyihija M, Killham K. Effect of Superphosphate and Arbuscular Mycorrhizal Fungus Glomus mosseae on phosphorus and Arsenic uptake in Lentil (Lens culinaris L). Water Air Soil Pollut -online first ${ }^{\mathrm{TM}} 4^{\text {th }}$ March (2011).

[41] Ricinus communis. Available at: www.botanical.com/botanical/ $\mathrm{mgmh} / \mathrm{c} / \mathrm{casoil32.html} \mathrm{(2011).}$

(C) Mwinyikione Mwinyihija; Licensee Bentham Open.

This is an open access article licensed under the terms of the Creative Commons Attribution Non-Commercial License (http://creativecommons.org/licenses/by$\mathrm{nc} / 3.0 /$ ), which permits unrestricted, non-commercial use, distribution and reproduction in any medium, provided the work is properly cited. 